Boston University School of Law

Scholarly Commons at Boston University School of Law

Faculty Scholarship

1997

Reefer Madness: The Federal Response to California's Medical-

Marijuana Law

George J. Annas

Follow this and additional works at: https://scholarship.law.bu.edu/faculty_scholarship

Part of the Health Law and Policy Commons 
Legal Issues in Medicine

\section{Reefer Madness - The Federal Response to California's Medical-Marijuana LaW}

\author{
George J. AnNAS, J.D., M.P.H.
}

M ARIJUANA is unique among illegal drugs in its political symbolism, its safety, and its wide use. More than 65 million Americans have tried marijuana, the use of which is not associated with increased mortality. ${ }^{1}$ Since the federal government first tried to tax it out of existence in 1937, at least partly in response to the 1936 film Reefer Madness, marijuana has remained at the center of controversy. Now physicians are becoming more actively involved. Most recently, the federal drug policy against any use of marijuana has been challenged by California's attempt to legalize its use by certain patients on the recommendation of their physicians. The federal government responded by threatening California physicians who recommend marijuana to their sick patients with investigation and the loss of their prescription privileges under Drug Enforcement Administration (DEA) regulations. ${ }^{2}$

The editor-in-chief of the Journal suggested that prohibiting physicians from helping their suffering patients by suggesting that they use marijuana is "misguided, heavy-handed, and inhumane." ${ }^{3} \mathrm{He}$ recommended that marijuana be reclassified as a Schedule II drug and made available by prescription without the usual requirement of controlled clinical trials. Many states, including Massachusetts, had previously passed laws that permitted their citizens to use marijuana for medicinal purposes under some circumstances. ${ }^{4}$ California's law seems to have engendered a uniquely harsh federal response because California is a large, trend-setting state; because its new marijuana law is very broad as compared with others; and because the law was passed by popular referendum. In this article I will discuss the new California law and its implications for physicians.

\section{THE CALIFORNIA PROPOSITION}

In the fall of 1996, California voters approved the Medical Marijuana Initiative (Proposition 215) by a vote of 56 to 44 percent. The act is entitled the Compassionate Use Act of 1996, and its purpose is to give Californians the right to possess and cultivate marijuana for medical purposes "where that medical use is deemed appropriate and has been recommended by a physician who has determined that the person's health would benefit from the use of marijuana in the treatment of cancer, anorexia, AIDS, chronic pain, spasticity, glaucoma, arthritis, migraine, or any other illness for which marijuana provides relief." Nothing in the act permits persons using marijuana for medical purposes to engage in conduct that endangers others (such as driving while under its influence), condones "the diversion of marijuana for nonmedical purposes," or permits the buying or selling of marijuana. ${ }^{5}$ The two operative sections of the law are as follows:

Notwithstanding any other provision of law, no physician in this state shall be punished, or denied any right or privilege, for having recommended marijuana to a patient for medical purposes.

[Existing California law] relating to the possession of marijuana [and the] cultivation of marijuana, shall not apply to a patient, or to a patient's primary caregiver [the person who has consistently assumed responsibility for the patient's housing, health, or safety] who possesses or cultivates marijuana for the personal medical purposes of the patient upon the written or oral recommendation or approval of a physician. ${ }^{5}$

The primary purpose of this law is to provide a specified group of patients with an affirmative defense to the charge of possession or cultivation of marijuana, the defense of medical necessity. To use this defense, the patient must be able to show that his or her physician recommended or approved of the use of marijuana, either orally or in writing. Obviously, a note from a physician is better evidence than a simple assertion that "my doctor said this would be good for me," and most patients will want a written statement to help protect them from problems with the police. Nothing in this law changes current law against buying or selling marijuana or affects federal law; it merely provides that qualified patients and their primary care givers can possess and cultivate their own marijuana for personal medicinal purposes, without violating state drug laws.

\section{COMPASSION AND THE USE OF UNAPPROVED DRUGS}

The federal government has been in the business of regulating drugs for almost a century, and few exceptions have ever been made to the basic rules of the Food and Drug Administration (FDA), even for patients with cancer or AIDS. In 1979, for example, the FDA was successful in convincing a unanimous U.S. Supreme Court that Congress intended no exception for terminally ill patients who sought to take laetrile, an unapproved drug, for cancer. The FDA's primary rationale was that the use of this unapproved and useless drug could prevent patients from seeking conventional treatments for cancer that offered them at least some chance of a cure. ${ }^{6}$ Under President Ronald Reagan, however, the FDA re- 
sponded with a great deal more flexibility to the AIDS epidemic and permitted the use and sale of drugs not yet approved (but in use in ongoing clinical trials) if, among other things, "the drug [was] intended to treat a serious or immediately lifethreatening disease." 7 More surprisingly, the FDA also permitted individual patients to import unapproved drugs from other countries for their personal, medical use. ${ }^{8}$ These regulations were almost purely political, had no scientific basis, and tended to conflate treatment and research and to undermine the very purpose of clinical trials. ${ }^{8}$ The theory used to justify these exceptions to federal drug laws was the very one rejected by the Supreme Court: terminally ill patients have "nothing to lose" and should not be deprived of the hope (even the false hope) that they might escape death. ${ }^{6,8}$

Given this history, it is not surprising that the advocates of the medicinal use of marijuana concentrate their reform efforts on helping patients with cancer ameliorate the adverse effects of chemotherapy and helping patients with AIDS counteract weight loss and fight their disease. Virtually no one thinks it is reasonable to initiate criminal prosecution of patients with cancer or AIDS who use marijuana on the advice of their physicians to help them through conventional medical treatment for their disease. Anecdotal evidence of the effectiveness of smoked marijuana abounds. ${ }^{9}$ Perhaps the most convincing is the account of Harvard professor and author Stephen Jay Gould, one of the world's first survivors of abdominal mesothelioma. When Gould started intravenous chemotherapy, he writes:

Absolutely nothing in the available arsenal of anti-emetics worked at all. I was miserable and came to dread the frequent treatments with an almost perverse intensity. I had heard that marijuana often worked well against nausea. I was reluctant to try it because I have never smoked any substance habitually (and didn't even know how to inhale). Moreover, I had tried marijuana twice [in the 1960s] ... . and had hated it. . . . Marijuana worked like a charm. . . . The sheer bliss of not experiencing nausea - and not having to fear it for all the days intervening between treatments - was the greatest boost I received in all my year of treatment, and surely the most important effect upon my eventual cure. ${ }^{10}$

Similarly, in patients with AIDS, marijuana has been credited with counteracting such side effects of treatment as severe nausea, vomiting, loss of appetite, and fatigue, as well as with stimulating the appetite to help prevent weight loss.

\section{THE WHITE HOUSE PRESS CONFERENCE}

Had the California proposition been limited to the use of marijuana for terminal illnesses such as cancer and AIDS, it would probably have caused much less concern. Arizona passed a much broader initiative that permitted physicians to prescribe any drug on Schedule I, but in April 1997, the Arizona legislature amended the law to apply only to drugs approved by the FDA, thus effectively repealing it. ${ }^{11}$ The California law applies only to marijuana but makes it available for a wide range of medical conditions, including anorexia, pain, spasticity, glaucoma, arthritis, migraine, "or any other illness for which marijuana provides relief." 5 This very broad definition of the potential medicinal uses of marijuana seemed an explicit endorsement of the drug itself, which the Clinton administration and others believed to be sending the wrong message to America's youth. After thinking about the issue for approximately two months, the Clinton administration announced that it would vigorously oppose the implementation of the California proposition and the Arizona law. ${ }^{2}$

Barry McCaffrey, director of the Office of National Drug Control Policy, announced at a White House news conference on December 30, 1996, that "nothing has changed. Federal law is unaffected by these propositions." ${ }^{2}$ McCaffrey expressed concern about marijuana as a "gateway drug" and about the potential impact of the law on children. As for the potential medicinal uses of marijuana, he said:

This is not a medical proposition. This is the legalization of drugs that we're concerned about. Here's what the medical advisor in the state of California saw as the potential uses of marijuana. [Here McCaffrey showed a slide.] . . . It includes recalling forgotten memories, cough suppressants, Parkinson's disease, writer's cramp. This is not medicine. This is a Cheech and Chong show. And now what we are committed to doing is to look in a scientific way at any proposition that would bring a new medicine to the assistance of the American medical establishment. ${ }^{2}$

Secretary of Health and Human Services Donna Shalala said that the initiatives reinforced the growing belief among Americans that marijuana is not harmful, whereas the administration remained "opposed to the legalization of marijuana [because] all available research has concluded that marijuana is dangerous to our health." ${ }^{2}$ Nonetheless, she did say that the National Institutes of Health (NIH) would continue to support and review "peer-reviewed" and "scientifically valid" research on "the possible usefulness of smoked marijuana in the limited circumstances where available medications have failed to provide relief for individual patients." 2

Finally, Attorney General Janet Reno announced that physicians who followed the terms of the California law would be the new targets of federal law enforcement (instead of drug dealers) and threatened physicians with loss of their registrations with the DEA and with exclusion from participation in Medicare and Medicaid. She stated:

Federal law still applies. . . . U.S. attorneys in both states will continue to review cases for prosecution and DEA of- 
ficials will review cases as they have to determine whether to revoke the registration of any physician who recommends or prescribes so-called Schedule I controlled substances. We will not turn a blind eye toward our responsibility to enforce federal law and to preserve the integrity of medical and scientific process to determine if drugs have medical value before allowing them to be used. ${ }^{2}$

\section{DOCTOR-PATIENT CONVERSATIONS}

Two basic issues are raised by the administration's position. One involves government regulation of doctor-patient conversations, and the other the quality of evidence necessary to make marijuana available by prescription. A group of California physicians filed suit against McCaffrey, Reno, and Shalala, arguing that the threats of prosecution against physicians for talking to their patients violate their First Amendment rights and interfere with their ability as physicians to use "their best medical judgment in the context of a bona fide physician-patient relationship." 12

In the only comparable case to reach the U.S. Supreme Court, the Court narrowly upheld a gag rule related to discussing abortion in a federally funded Title $\mathrm{X}$ family-planning clinic. ${ }^{13}$ The Court upheld the gag rule because Congress could reasonably limit the types of medical services available at a federally funded facility. ${ }^{14}$ The Court was able to sidestep the First Amendment issue because patients (at least in theory) had access to other doctors who had an obligation to furnish them with full information, and the doctor-patient relationship in a Title $\mathrm{X}$ clinic was characterized as not "all-encompassing" but, rather, as limited only to preconception counseling:

The Title X program regulations do not significantly impinge upon the doctor-patient relationship. Nothing in them requires a doctor to represent as [his or her] own any opinion that [he or she] does not in fact hold. Nor is the doctor-patient relationship established by expectation on the part of the patient of comprehensive medical advice. The program does not provide post-conception medical care, and therefore a doctor's silence with regard to abortion cannot reasonably be thought to mislead a client into thinking that the doctor does not consider abortion an appropriate option for her. ${ }^{13}$

Even if one accepts this unconvincing rationale, it is impossible to apply it to California physicians who believe that marijuana would be beneficial for their patients and who are providing their overall health care. Patients receiving care for cancer or AIDS rightfully and reasonably expect and are entitled to full disclosure and discussion of available treatment options. The California physicians are on strong legal ground with their lawsuit, and they should prevail. In early April, U.S. District Court judge Fern M. Smith granted a preliminary injunction prohibiting the DEA from carrying out its threats against California physicians and encouraged the litigants to try to work out a settlement of the dispute. ${ }^{15}$

In response to the lawsuit and the growing opposition to its threats to physicians, the administration issued a clarifying letter, essentially stating that physicians may discuss marijuana with their patients so long as they do not recommend its use. ${ }^{16}$ This provides no guidance at all. Of course doctors can talk to patients; the question is what they can tell them. The real subject of dispute remains whether physicians can "recommend" marijuana (and thereby grant their patients immunity from state prosecution), as the California proposition provides. Would, for example, telling a patient with cancer that other physicians have reported that marijuana has given their patients relief from nausea constitute a "recommendation"?

Judge Smith made it clear that the First Amendment protects physician-patient communications and that the government has no authority to determine the content of physicians' speech. ${ }^{15}$ She also concluded that the federal statements regarding threatened prosecution were vague and thus could lead to physicians' censuring their own speech to avoid possible federal prosecution. On the other hand, she noted (correctly) that the First Amendment does not protect "speech that is itself criminal because [the speech is] too intertwined with illegal activity." 15 Under federal drug laws, which cannot be affected by legislation in California, it remains a crime for physicians to aid, abet, or conspire - by speech or action - to violate federal criminal statutes. Thus, it is not a violation of the First Amendment for the federal government to prosecute or threaten to prosecute physicians who specifically intend to aid, abet, or conspire with their patients to violate federal drug laws.

Judge Smith could have added that to prevail in such a case the government will have to prove more than simply that the physician recommended marijuana as worth trying for a medical condition. The "more" will include evidence that the physician "associated himself with the venture" of illegally purchasing marijuana "as something he wished to bring about and sought by his actions to make succeed." 17 This should require at least that the physician identify a source of the marijuana, and some connection between that source and the physician. ${ }^{18}$ It is only speech short of this that the injunction covers. Of course, this formulation still leaves it uncertain exactly how far physicians may go in recommending marijuana use before the federal government is justified in prosecuting them for criminal behavior. Judge Smith concluded with an understatement: "This injunction does not provide physicians with the level of certainty for which they had hoped." 15 


\section{MARIJUANA AS MEDICINE}

Attempts to have marijuana reassigned from Schedule I to Schedule II began almost immediately after Congress passed the Uniform Controlled Substances Act of 1970, which established the current system of drug classification. The following findings must be made to place a drug on Schedule I: "(A) The drug ... . has a high potential for abuse; (B) The drug . . . has no currently accepted medical use in treatment in the United States; and (C) there is a lack of accepted safety for use of the drug under medical supervision." Part A for Schedule II drugs is identical; the other requirements are "(B) The drug . . . has a currently accepted medical use in treatment in the United States . . . and (C) Abuse of the drug . . . may lead to severe psychological or physical dependence."

In 1988, after two years of hearings, DEA administrative-law judge Francis Young recommended shifting marijuana to Schedule II on the grounds that it was safe and had a "currently accepted medical use in treatment." 19 Specifically, Judge Young found that "marijuana, in its natural form, is one of the safest therapeutically active substances known to man. . . . At present it is estimated that marijuana's LD-50 [median lethal dose] is around 1:20,000 or $\mathrm{l}: 40,000$. In layman's terms . . . a smoker would theoretically have to consume 20,000 to 40,000 times as much marijuana as is contained in one marijuana cigarette . . . nearly 1500 pounds of marijuana within about fifteen minutes to induce a lethal response." As for medical use, the judge concluded, among other things, that marijuana "has a currently accepted medical use in treatment in the United States for nausea and vomiting resulting from chemotherapy treatments." 19 The administrator of the DEA rejected Young's recommendation, on the basis that there was no scientific evidence showing that marijuana was better than other approved drugs for any specific medical condition. Further attempts to get the courts to reclassify marijuana have been unsuccessful.

Reacting to a DEA suggestion that only a "fringe group" of oncologists accepted marijuana as an antiemetic agent, a survey of a random sample of the members of the American Society of Clinical Oncology was undertaken in $1990 .{ }^{20}$ More than 1000 oncologists responded to the survey, and 44 percent of them reported that they had recommended marijuana to at least one patient. ${ }^{20}$ Marijuana was believed to be more effective than oral dronabinol (Marinol) by the respondents: of those who believed they had sufficient information to compare the two drugs directly, 44 percent believed marijuana was more effective, and only 13 percent believed dronabinol was more effective. ${ }^{20}$ Of course, nothing in the FDA regulations requires a drug to be more effective than an existing one for it to be approved. Nonetheless, in the current anti-marijuana climate, the NIH has consistently refused to fund research on marijuana. In the wake of the California proposition, this position is no longer tenable.

An NIH panel, after a two-day workshop in February, recommended research on marijuana in the areas of wasting associated with AIDS, nausea due to cancer chemotherapy, glaucoma, and neuropathic pain. $^{21}$ This list seems reasonable, especially since objective criteria such as weight gain, intraocular pressure, and the frequency of vomiting can be used to determine the drug's effectiveness.

Such research may be difficult to do, but it is possible to compare orally administered dronabinol with smoked marijuana. Some argue that because the symptoms of nausea are so subjective and "extremely difficult to quantify in controlled experiments," marijuana should be available as a prescription drug on a compassionate basis. ${ }^{3}$ In fact, current FDA regulations provide the authority for making marijuana available on a compassionate basis while such studies are proceeding. Other support for its compassionate use would appear to come from the Clinton administration's solicitor general, Walter Dellinger, who argued before the Supreme Court less than two weeks after the McCaffrey-Reno press conference that the administration believed that Americans had a weak constitutional right "not to suffer." Although Dellinger said he did not believe this right was broad enough to prohibit the states from making physician-assisted suicide for terminally ill patients a crime, it should certainly be broad enough to prohibit the federal government from denying patients with cancer and AIDS access to drugs that could help them withstand potentially life-saving treatments.

\section{WHAT ABOUT THE CHILDREN?}

The final argument that the administration makes against any medical use of marijuana is that this would send the "wrong message" to children, who would then use this "gateway drug" and get hooked on much more harmful substances, such as cocaine and heroin. There are two responses to this argument. The first is provided by Boston Globe columnist Ellen Goodman, who asks, "What is the infamous signal being sent to [children]? . . . If you hurry up and get cancer, you, too, can get high?" 22

The second response relates to the "gateway" issue itself. A 1994 survey found that 17 percent of current marijuana users said they had tried cocaine and only 0.2 percent of those who had not used marijuana had tried cocaine. ${ }^{23}$ One way to interpret these data is that children who smoke marijuana are 85 times as likely as others to try cocaine; another is that 83 percent of pot smokers, or five out of six, never try cocaine. ${ }^{23}$ Honesty is likely to make a greater and more lasting impression on our children 
than political posturing and hysteria. Many people want to make marijuana legal for everyone. But opposition to the legalization of marijuana generally is not a good reason to keep it from patients who are suffering. Making marijuana a Schedule II drug does not make it widely acceptable or available any more than classifying medicinal cocaine as a Schedule II drug made it acceptable or available.

\section{CONCLUSIONS}

Doctors are not the enemy in the "war" on drugs; ignorance and hypocrisy are. Research should go on, and while it does, marijuana should be available to all patients who need it to help them undergo treatment for life-threatening illnesses. There is certainly sufficient evidence to reclassify marijuana as a Schedule II drug. Unlike quack remedies such as laetrile, marijuana is not claimed to be a treatment in itself; instead, it is used to help patients withstand the effect of accepted treatment that can lead to a cure or amelioration of their condition. As long as a therapy is safe and has not been proved ineffective, seriously ill patients (and their physicians) should have access to whatever they need to fight for their lives.

\section{REFERENCES}

1. Sidney S, Beck JE, Tekawa IS, Quesenberry CP Jr, Friedman GD. Marijuana use and mortality. Am J Public Health 1997;87:585-90.
2. Federal News Service. White House briefing news conference, December 30, 1996

3. Kassirer JP. Federal foolishness and marijuana. N Engl J Med 1997;336: 366-7.

4. Mass. Gen. Laws, Ch. 94D, $\$ 2$ (West 1996).

5. Cal. Code Sec. 11362.5 (1996).

6. United States v. Rutherford, 442 U.S. 544 (1979).

7. Treatment Use of an Investigational New Drug, 21 C.F.R. $\$ 312.34$

(1988).

8. Annas GJ. Faith (healing), hope and charity at the FDA: the politics of AIDS drugs trials. Villanova Law Rev 1989;34:771-97.

9. Grinspoon L, Bakalar JB. Marihuana: the forbidden medicine. New Haven, Conn.: Yale University Press, 1995.

10. Gould SJ. It worked like a charm. The Times. May 4, 1993.

11. Golden T. Medical use of marijuana to stay illegal in Arizona. New York Times. April 17, 1997:Al4

12. Conant v. McCaffrey, U.S. D.C. No. Cal., No. C97-0139 FMS (1997). 13. Rust v. Sullivan, 500 U.S. 173 (1991).

14. Annas GJ. Restricting doctor-patient conversation in federally funded clinics. N Engl J Med 1991;325:362-4.

15. Golden T. Federal judge supports California doctors on marijuana issue. New York Times. April 12, 1997:7.

16. Stapleton S. Medical pot: Feds say talk is OK, just don't recommend it. American Medical News. March 17, 1997:1, 33.

17. Morei v. U.S., 127 F2d. 827 (6 Cir. 1942).

18. State v. Gladstone, 474 P2d. 274 (Wash. 1970).

19. In the Matter of Marijuana Rescheduling Petition, U.S. Dept. of Justice, DEA, Docket No. 86-22, Sept. 6, 1988 (Young, J.).

20. Doblin RE, Kleiman MA. Marijuana as antiemetic medicine: a survey of oncologists' experiences and attitudes. J Clin Oncol 1991;9:1314-9.

21. Leary WE. U.S. panel urges study of medical marijuana. New York

Times. February 21, 1997:A27.

22. Goodman E. Clear thinking in the medical marijuana debate. Boston Globe. February 2, 1997:C7.

23. Wren CS. Phantom numbers haunt the war on drugs. New York Times. April 20, 1997:4E.

(C)1997, Massachusetts Medical Society.

RECEIVE THE JOURNAL'S TABLE OF CONTENTS EACH WEEK BY E-MAIL

To receive the table of contents of the New England Journal of Medicine by e-mail every Thursday morning, send an e-mail message to:

listserv@massmed.org

Leave the subject line blank, and type the following as the body of your message:

subscribe TOC-L

You can also sign up through our website at: http://www.nejm.org 